\title{
Host Resistance and Chemical Control for Management of Sclerotinia Stem Rot of Soybean in Ohio
}

\author{
Jaqueline Huzar-Novakowiski, Pierce A. Paul, and Anne E. Dorrance
}

Department of Plant Pathology, The Ohio State University, Ohio Agricultural Research and Development Center, Wooster 44691. Accepted for publication 3 April 2017.

\begin{abstract}
Recent outbreaks of Sclerotinia stem rot (SSR) of soybean in Ohio, along with new fungicides and cultivars with resistance to this disease, have led to a renewed interest in studies to update disease management guidelines. The effect of host resistance (in moderately resistant [MR] and moderately susceptible [MS] cultivars) and chemical control on SSR and yield was evaluated in 12 environments from 2014 to 2016. The chemical treatments evaluated were an untreated check, four fungicides (boscalid, picoxystrobin, pyraclostrobin, and thiophanate-methyl), and one herbicide (lactofen) applied at soybean growth stage R1 (early flowering) alone or at R1 followed by a second application at R2 (full flowering). SSR developed in 6 of 12 environments, with mean disease incidence in the untreated check of 2.5 to

$41 \%$. The three environments with high levels of SSR (disease incidence in the untreated check $>20 \%$ ) were used for further statistical analysis. There were significant effects $(P<0.05)$ of soybean cultivar and chemical treatment on SSR levels. Significantly lower levels of SSR were observed in MR cultivars. Both boscalid and lactofen reduced SSR but did not increase yield. Pyraclostrobin increased SSR compared with the untreated check in the three environments with high levels of disease. In the six fields where SSR did not develop, chemical treatment did not increase yield, nor was the yield from the MR cultivar significantly different from the MS cultivar. For Ohio, MR cultivars alone were effective for management of SSR in soybean fields where this disease has historically occurred.
\end{abstract}

Sclerotinia stem rot (SSR) or white mold of soybean is caused by the necrotrophic fungus Sclerotinia sclerotiorum (Lib.) de Bary. In the United States, it is estimated that this disease caused losses of over 329 million bushels of soybean from 1996 to 2014 (http://extension. cropsciences.illinois.edu/fieldcrops/diseases/yield_reductions.php). In Ohio, localized outbreaks of SSR have been reported in each of the past 8 years (A. E. Dorrance, personal communication). Soybean producers have been applying chemicals to manage SSR (A. E. Dorrance, unpublished data) but chemical control has had inconsistent results in disease management (Martin and Dorrance 2014, 2015).

Management of SSR is very challenging, especially because S. sclerotiorum has a wide host range (Boland and Hall 1994) and, once the pathogen is introduced into a field, it has the ability to survive as sclerotia in the soil for many years (Adams and Ayers 1979). If cool and wet conditions occur (Boland and Hall 1987, 1988a; Weiss et al. 1980b), sclerotia may germinate, producing apothecia and ascospores which can be dispersed, land on a host plant, and cause infection. Flowers are the primary infection sites for S. sclerotiorum in soybean (Boland and Hall 1988a), and whether or not the specific environmental conditions occur prior to and during the flowering stage varies greatly from year to year and field to field (Abawi and Grogan 1975; Boland and Hall 1987; Grogan and Abawi 1975; Weiss et al. 1980b).

Host resistance is considered one of the most effective tactics for plant disease management. Resistance to $S$. sclerotiorum is polygenic (Guo et al. 2008; Huynh et al. 2010; Kim and Diers 2000) and, though complete resistance has not been reported, partial resistance is available (Hoffman et al. 2002; Kim et al. 2000; Kull et al. 2003; Rousseau et al. 2004; Vuong et al. 2004). Typically, low correlation for resistance to $S$. sclerotiorum between controlled laboratory and

Corresponding author: A. E. Dorrance; E-mail address: dorrance.1@osu.edu

*The $\boldsymbol{e}$-Xtra logo stands for "electronic extra" and indicates that one supplementary table is published online.

(C) 2017 The American Phytopathological Society greenhouse assays compared with field studies was observed; consequently, field tests should be used to confirm the level of resistance of a soybean cultivar (Kim et al. 2000). Recently, it was also suggested that the $S$. sclerotiorum isolate used for screenings may affect the results for SSR severity in greenhouse assays (Willbur et al. 2017). In addition, this lack of correlation between physiological resistance and field response is thought to be due to disease escape mechanisms associated with early flowering and maturity, less lodging, and upright and open canopy (Buzzel et al. 1993; Kim and Diers 2000; Kim et al. 2000; Miklas et al. 2013). Thus, considering that new soybean cultivars with high, moderate, and low levels of resistance to SSR have been released, field studies over a range of environments are required to evaluate their performance as a management tool for SSR.

There are several products labeled for management of SSR of soybean, including fungicides classified as demethylation inhibitors (flutriafol, prothioconazole, and tetraconazole), methyl benzimidazole carbamates (thiophanate methyl), succinate dehydrogenase inhibitors (SDHI) (boscalid), and quinone outside inhibitors (QoI) (picoxystrobin). The primary infection sites for $S$. sclerotiorum on soybean are the blossoms on the lower stem nodes that are 10 to $40 \mathrm{~cm}$ above the soil line (Boland and Hall 1988a); thus, there is a very narrow window available for fungicide applications. Two previous studies indicated that applications at the R1 growth stage (beginning flowering) reduced the incidence of disease compared with a single application at the R3 growth stage (beginning pod) (Mueller et al. 2002, 2004). Two applications of thiophanate-methyl starting at R1 or R2 (full flowering) followed by a second application 2 weeks later also had lower incidence of SSR compared with a single application at R1 (Mueller et al. 2004). Recent fungicide efficacy studies for SSR in the north-central region of the United States, including those in Ohio, have reported inconsistent results depending on the type of fungicide applied as well as the application timing (Byrne and Chilvers 2014, 2015, 2016; Huzar Novakowiski et al. 2016; Martin and Dorrance 2014, 2015; Mueller et al. 2016; Smith et al. 2015).

In addition to fungicides, the herbicide lactofen has been evaluated as another management tool for SSR. Lower disease 
incidence (DI) and disease severity occurred following applications of lactofen at R1 (Dann et al. 1999). However, results from that same study also showed a decrease in yield by as much as $10 \%$ when lactofen was used in the absence of SSR. This herbicide modifies the soybean canopy, delays flowering, and induces systemic acquired resistance response with an increase of phytoalexin production (Cheng et al. 2011; Dann et al. 1999; Landini et al. 2003). There are now newer formulations of herbicides containing lactofen that appear to be less phytotoxic to soybean plants (M. Loux, personal communication). The effect of these newer formulations of lactofen on the development of SSR and yield, especially when DI is low, are unknown.

Soybean cultivars with higher levels of resistance may, in part, play a role in the variable response of fungicides as a disease management tool for SSR. Hence, with the overall goal of improving SSR management recommendations, the objectives of this study were to evaluate (i) the response of cultivars with different levels of resistance under field conditions, (ii) the efficacy of chemical control, and (iii) the interaction of soybean cultivars and chemical control for management of SSR in Ohio.

\section{MATERIALS AND METHODS}

Field environments. In total, 2, 5, and 5 field experiments were carried out in 2014, 2015, and 2016, respectively, for a total of 12 environments. The fields were located in northeast and northcentral Ohio, where SSR of soybean occurs most frequently. All of the fields chosen for this study have a long history of the disease; therefore, there was no artificial inoculation. A summary of field site characteristics, source of seed, ratings of soybean cultivars, and dates of activities is provided in Table 1. The cultivars were planted by the cooperating producer with seeding rates varying from 395,200 to 445,000 seeds ha ${ }^{-1}$, and corn was the previous crop for all fields. The size of the experiment varied from approximately 3,280 to $8,755 \mathrm{~m}^{2}$, depending on the number of cultivars and replicated blocks.

At each location, a WatchDog 1425 Data Logger (Spectrum Technologies, Inc., Aurora, IL) was placed in the field within 2 weeks after planting to record air temperature, relative humidity, soil temperature, soil moisture, and leaf surface wetness. Air temperature and relative humidity sensors were placed above the soybean canopy, whereas the leaf surface wetness sensor was placed at approximately $15 \mathrm{~cm}$ from the soil surface.

Experimental design and treatments. The experimental design was a randomized complete block, with a split-plot-type arrangement of cultivar as whole plot and chemical treatment as subplot. There were four to eight replicate blocks in each experiment and, in each block, pairs of strips of each of two to six cultivars were planted. Each strip was then divided into subplots to which chemical treatments were randomly assigned, while the other was left untreated, serving as a control to generate data on baseline disease and yield levels at each plot location across the field. Each experimental unit (subplot) was $1.5 \mathrm{~m}$ wide (four rows) by $9 \mathrm{~m}$ long, with $38-\mathrm{cm}$ row spacing.

The soybean cultivars selected for this study were based on reported levels of resistance to $S$. sclerotiorum provided by the seed companies (Table 1). The cultivars were not the same across years and locations but similar levels of resistance were identified. In each experiment, at least one cultivar with moderately high and another with moderately low levels of resistance and similar maturity group were used.

Four different fungicides and one herbicide were applied at the R1 growth stage (50\% of plants with one flower open on the main stem) alone or at R1 followed by an application at R2 (full flowering, $50 \%$ of plants with an open flower at one of the two uppermost nodes on the main stem) for a total of 10 treatment combinations (Table 2). Chemical treatments were applied with a

TABLE 1. Location, soybean cultivars, and activities performed in field experiments to evaluate the effect of host resistance and chemical control to manage Sclerotinia stem rot of soybean in Ohio during 2014, 2015, and $2016^{\mathrm{a}}$

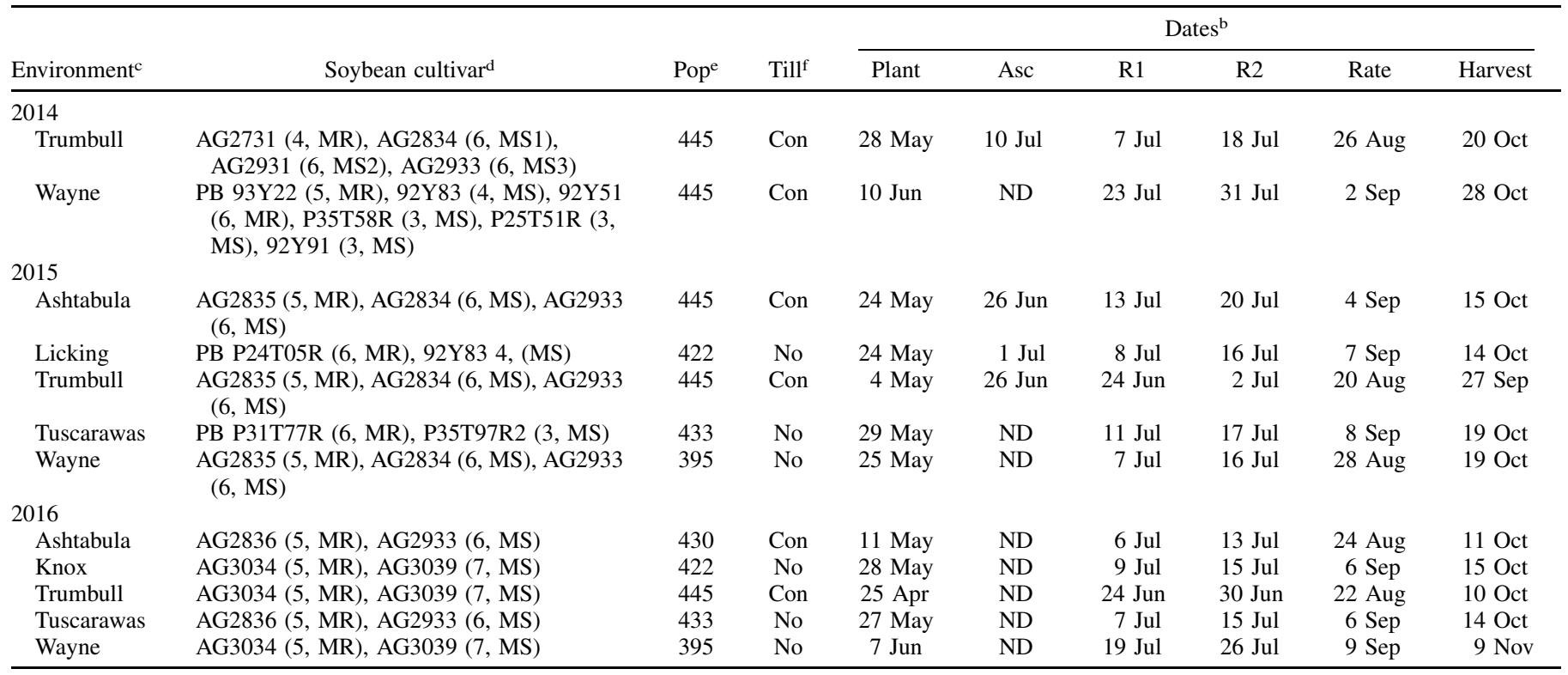

a All fields were planted at $38-\mathrm{cm}$ row spacing and had corn as the previous crop.

b Abbreviations: Plant $=$ planting, Asc $=$ detection of Sclerotinia sclerotiorum ascospores by the blue plate method, R1 = fungicide application at R1 growth stage (beginning flowering = at least one open flower in the main stem), R2 = fungicide application at R2 growth stage (full flowering = open flower at one of the two uppermost nodes of the main stem), Rate $=$ Disease rating, Jun $=$ June, Jul $=$ July, Aug $=$ August, Sep $=$ September, Oct $=$ October, Nov $=$ November, and ND $=$ not detected.

c Year and county in Ohio.

${ }^{\mathrm{d}}$ Soybean cultivars and Sclerotinia stem rot rating (in parentheses): Asgrow (AG) on a 1-to-9 scale, where $1=$ resistant; and Pioneer Brand (PB) on a 1-to-9 scale, where $1=$ susceptible. $\mathrm{MR}=$ moderately resistance and $\mathrm{MS}=$ moderately susceptible.

e Seed population $\left(\times 10^{3} \mathrm{ha}^{-1}\right)$.

${ }_{\mathrm{f}}$ Tillage: Con $=$ conventional and No $=$ no-till. 
$\mathrm{CO}_{2}$ pressurized backpack sprayer (R\&D Sprayers, BellSpray Inc., Opelousas, LA) calibrated to deliver 187 liters $\mathrm{ha}^{-1}$ at $276 \mathrm{kPa}$ using flat fan spray nozzle XR8001 (Teejet Technologies, Dillsburg, PA) spaced $50 \mathrm{~cm}$ apart. A nonionic surfactant (Spreader 90; Loveland Products, Greeley, CO) was added at $0.25 \% \mathrm{vol} \mathrm{vol}^{-1}$ to the spray volume for all treatments. Even though pyraclostrobin is not labeled specifically for SSR in the United States, it was included in the experiment because this fungicide is labeled for disease management and plant health in soybean.

Monitoring for the presence of ascospores. The blue plate method was used to monitor the presence of ascospores of S. sclerotiorum at all field sites. Blue plates consisted of Petri dishes (15 by $100 \mathrm{~mm}$ ) containing a semiselective media (potato dextrose agar at $39 \mathrm{~g} \mathrm{liter}^{-1}$, pentachloronitrobenzene at $25 \mathrm{mg} \mathrm{liter}^{-1}$, penicillin at $150 \mathrm{mg} \mathrm{liter}^{-1}$, streptomycin at $150 \mathrm{mg} \mathrm{liter}^{-1}$, and bromophenol blue at $50 \mathrm{mg} \mathrm{liter}^{-1}$ ) (Steadman et al. 1994). Thirty plates were placed randomly across the field experiment under the soybean canopy between growth stages V5 (fifth trifoliate) and R3 (beginning pod), with the lids removed for approximately $3 \mathrm{~h}$ between 9:30 A.M. and 1:30 P.M. (Parker et al. 2014) one to three times per week, depending on weather conditions. After exposure, the plates were covered, collected, and maintained at room temperature in the dark for 3 to 5 days (Foster et al. 2011). S. sclerotiorum produces oxalic acid as it grows on the media which causes a change in $\mathrm{pH}$, turning the media from blue to yellow. The plates were evaluated for the presence of yellow halos. Based on earlier reports that other fungi such as Botrytis, Penicillium, and Aspergillus spp. may also turn the culture media yellow, suspected colonies were subcultured onto another Petri dish containing semiselective media and monitored for growth and production of sclerotia to confirm the presence of $S$. sclerotiorum (Foster et al. 2011; Parker et al. 2014).

Disease ratings and harvest. The incidence and severity of SSR were evaluated at the R6 growth stage in each plot with a rating scale previously described (Grau et al. 1982) (Fig. 1). Briefly, 30 plants were rated in each plot for the presence or absence of SSR, and DI was expressed in percentage [(symptomatic plants/30) $\times 100]$.

TABLE 2. Chemical treatments used in the field experiments for management of Sclerotinia stem rot of soybean in Ohio

\begin{tabular}{|c|c|c|c|c|}
\hline Treatment & Growth stage ${ }^{a}$ & Commercial product & Rate (a.i. ha ${ }^{-1}$ ) & Company $^{\mathrm{b}}$ \\
\hline Untreated check & $\ldots$ & $\ldots$ & $\ldots$ & $\ldots$ \\
\hline Boscalid & $\mathrm{R} 1$ & Endura WG & $0.63 \mathrm{~kg}$ & BASF \\
\hline Boscalid & $\mathrm{R} 1+\mathrm{R} 2$ & Endura WG & $0.63+0.63$ & BASF \\
\hline Lactofen & R1 & Phoenix EC & 0.58 liter & Valent \\
\hline Pyraclostrobin & $\mathrm{R} 1$ & Headline SC & 0.88 liter & BASF \\
\hline Pyraclostrobin & $\mathrm{R} 1+\mathrm{R} 2$ & Headline SC & 0.88 liter +0.88 liter & BASF \\
\hline Picoxystrobin & $\mathrm{R} 1$ & Aproach SC & 0.73 liter & E. I. du Pont de Nemours \\
\hline Picoxystrobin & $\mathrm{R} 1+\mathrm{R} 2$ & Aproach SC & 0.73 liter +0.73 liter & E. I. du Pont de Nemours \\
\hline Thiophanate-methyl & $\mathrm{R} 1$ & Topsin 4.5 FL & $1.2 \mathrm{~kg}$ & United Phosphorous \\
\hline Thiophanate-methyl & $\mathrm{R} 1+\mathrm{R} 2$ & Topsin 4.5 FL & $1.2 \mathrm{~kg}+1.2 \mathrm{~kg}$ & United Phosphorous \\
\hline
\end{tabular}

a Growth stage: R1 refers to beginning flowering, when at least 50\% of the plants have an open flower in any node in the main stem, and R2 refers to full flowering, when at least $50 \%$ of the plants have an open flower at one of the two uppermost nodes in the main stem.

b BASF, Research Triangle Park, NC; Valent, Walnut Creek, CA; E. I. du Pont de Nemours and Company, Wilmington, DE; and United Phosphorous, King of Prussia, PA.
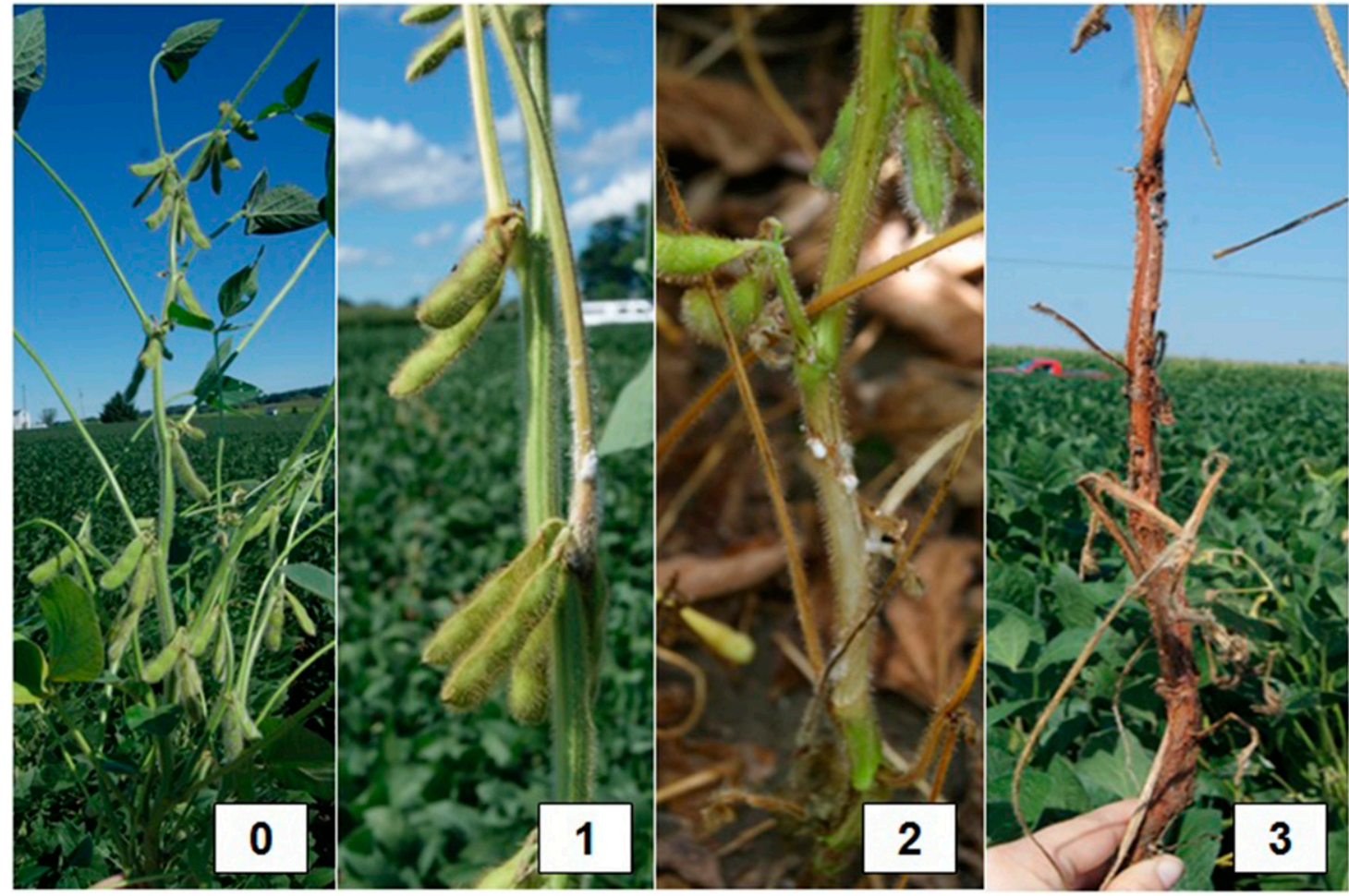

Fig. 1. Symptoms of Sclerotinia stem rot (SSR) and signs of Sclerotinia sclerotiorum on soybean plants in the field. Scale evaluated disease severity index (DSI) according to Grau et al. (1982), where $0=$ no symptoms, $1=$ symptoms on lateral branches only, $2=$ symptoms on main stem but little or no effect on pod filling, and $3=$ lesions on main stem causing plant death. 
Each of the 30 plants was also evaluated for disease severity and given a score of $0=$ no symptoms, $1=$ symptoms on lateral branches only, $2=$ symptoms on main stem but little or no effect on pod filling, and $3=$ lesions on main stem causing plant death. Disease severity index
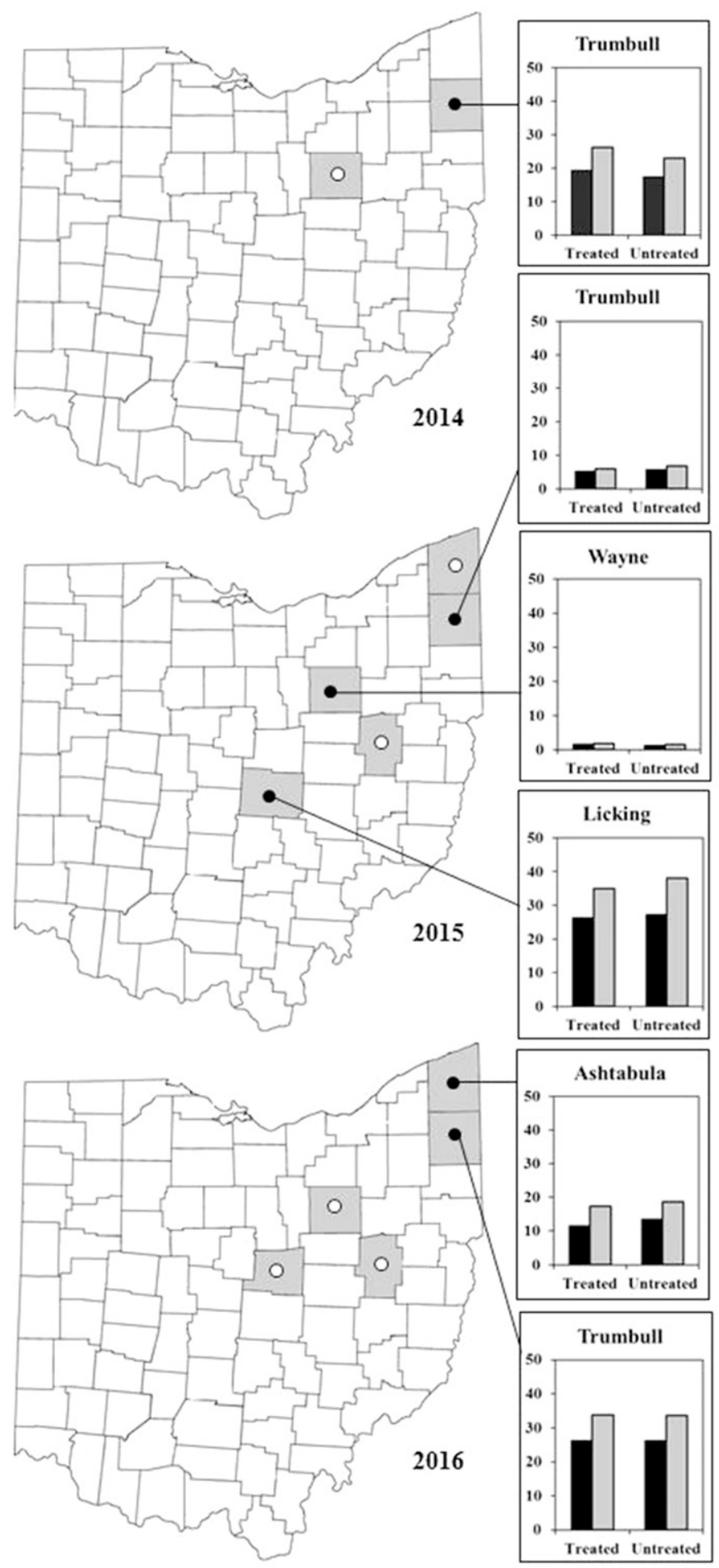

Field trials

0 Disease not present

Disease present

(DSI) ranged from 0 (no disease) to 100 (all plants were dead) and was calculated using the formula (Grau et al. 1982) DSI $=\sum[$ (score $\times$ number of plants with the specific severity score $\times 100) /($ total number of plants evaluated $\times 3$ )].

Plots in Wayne County were harvested with an Almaco SPC20 (Almaco, Nevada, IA) combine equipped with the HarvestMaster GrainGages System paired with an Allegro MX (Juniper Systems, Logan, UT) handheld computer for data recording. Harvest in other locations was performed by Tech Services, Inc. (Bluffton, IN) with a Massey Ferguson 8xp combine equipped with Almaco LRX electronics (Juniper Systems). Grain yields from all locations were adjusted to $13.5 \%$ moisture and the results were expressed in kilograms per hectare.

Data analysis. Overall means of DI and DSI were calculated for the treated and untreated paired plots in each environment (yearlocation). Thereafter, environments were classified in three categories based on overall mean DI: absence (no disease), low levels $(<20 \%)$, and moderate to high levels $(>20 \%)$. Fields in each category were then analyzed separately. Linear mixed-model covariance analysis was performed using PROC GLIMMIX of SAS (SAS Inc., Cary, NC) to determine the effects of cultivar and chemical treatment program on DI, DSI, and yield for those fields with moderate to high levels of DI, and on yield alone for environments without SSR. Cultivars were grouped based on resistance reaction as moderately resistant (MR) and moderately susceptible (MS) for statistical analysis. Cultivar, chemical treatment program, and their interaction were considered fixed effects while experiment, block, and all interactions involving experiment and block were treated as random effects. DSI from the untreated paired plot was used as a continuous covariate for the analyses in order to account and adjust for the influence of variability in baseline DSI across the field on cultivar and chemical treatment effects. Because DI was quantified as percentage, it was transformed to arcsine square root ( $\operatorname{arcDI})$ prior to statistical analysis. For environments without SSR, yield from the untreated paired plots was used as the covariate to account for the variability across the field. Each environment was first analyzed separately following the statistical model:

$$
\begin{aligned}
y_{i j k l}= & \theta+\alpha_{i}+\beta_{j}+(\alpha \beta)_{i j}+\delta X_{k}+\Delta_{i} X_{k}+\gamma_{j} X_{k}+\vartheta_{i j} X_{k} \\
& +b_{l}+(a b)_{i l}+\beta(a b)_{i j l}+e_{i j k l}
\end{aligned}
$$

where $y_{i j k l}=$ response variable $(\operatorname{arcDI}$, DSI, or yield); $\theta=$ the constant; $\alpha_{i}=$ effect of the $i$ th cultivar; $\beta_{j}=$ effect of the $j$ th chemical treatment program; $(\alpha \beta)_{i j}=$ effect of the $i$ th cultivar $-j$ th chemical treatment program interaction; $X_{k}=$ the $k$ th observation for the covariate; $\delta=$ effect of the covariate; $\Delta_{i}=$ interaction effect of cultivar and the covariate; $\gamma_{j}=$ interaction effect of chemical treatment program and the covariate; $\vartheta_{i j}=$ interaction of cultivar, chemical treatment program, and the covariate; $b_{l}=$ effect of $l$ th block; $(a b)_{i l}=$ effect of $i$ th cultivar $-l$ th block interaction; $\beta(a b)_{i j l}=$ effect of the $j t h$ chemical treatment within the ith cultivar within the $l t h$ block; and $e_{i j l}=$ residual. For the pooled data, the model was:

$$
\begin{aligned}
y_{i j k l}= & \theta+\alpha_{i}+\beta_{j}+(\alpha \beta)_{i j}+\delta X_{k}+\Delta_{i} X_{k}+\gamma_{j} X_{k}+\vartheta_{i j} X_{k}+\varphi_{m} \\
& +b(\varphi)_{l m}+\alpha(b \varphi)_{i l m}+\beta(\alpha b \varphi)_{i j l m}+e_{i j k l m}
\end{aligned}
$$

where $\varphi_{m}=$ effect of $m$ th environment (year-location), $b(\varphi)_{l m}=$ effect of the $l$ th block nested within $m$ th environment, $\alpha(b \varphi)_{i l m}=$ effect of the $i$ th cultivar nested within the $l$ th block within the $m$ th environment, and $\beta(\alpha b \varphi)_{i j l m}=$ the effect $j$ th chemical treatment program nested within the $i$ th cultivar within the $l$ th block within the $m$ th environment. All the other terms were the same as described for equation 1 . Initially, the covariance analysis was performed with all possible interactions. The nonsignificant terms $(P>0.05)$ were then removed from the analysis. Thereafter, lsmeans statements were used to compare the main and simple effect means for all significant fixed effects and interactions. 
Mixed-model regression analysis was used to study the relationships between SSR and yield as influenced by cultivar resistance. Models similar to those described in equations 1 and 2 were refitted to the data and regression coefficients were estimated for the relationship between yield and DSI. Intercepts and slopes were estimated for each cultivar when the analysis was performed for each environment individually. When the analysis was performed with the pooled data, coefficients were estimated for cultivars grouped in two categories (MR or MS). The intercepts and slopes were compared among cultivars or between resistance categories using the estimate statement in PROC GLIMMIX.

\section{RESULTS}

Detection of primary inoculum and DI. SSR developed in 6 of the 12 environments (Fig. 2). The mean, maximum and minimum daily values of environmental conditions recorded 10 days prior to fungicide application at R1 to 10 days post fungicide application at
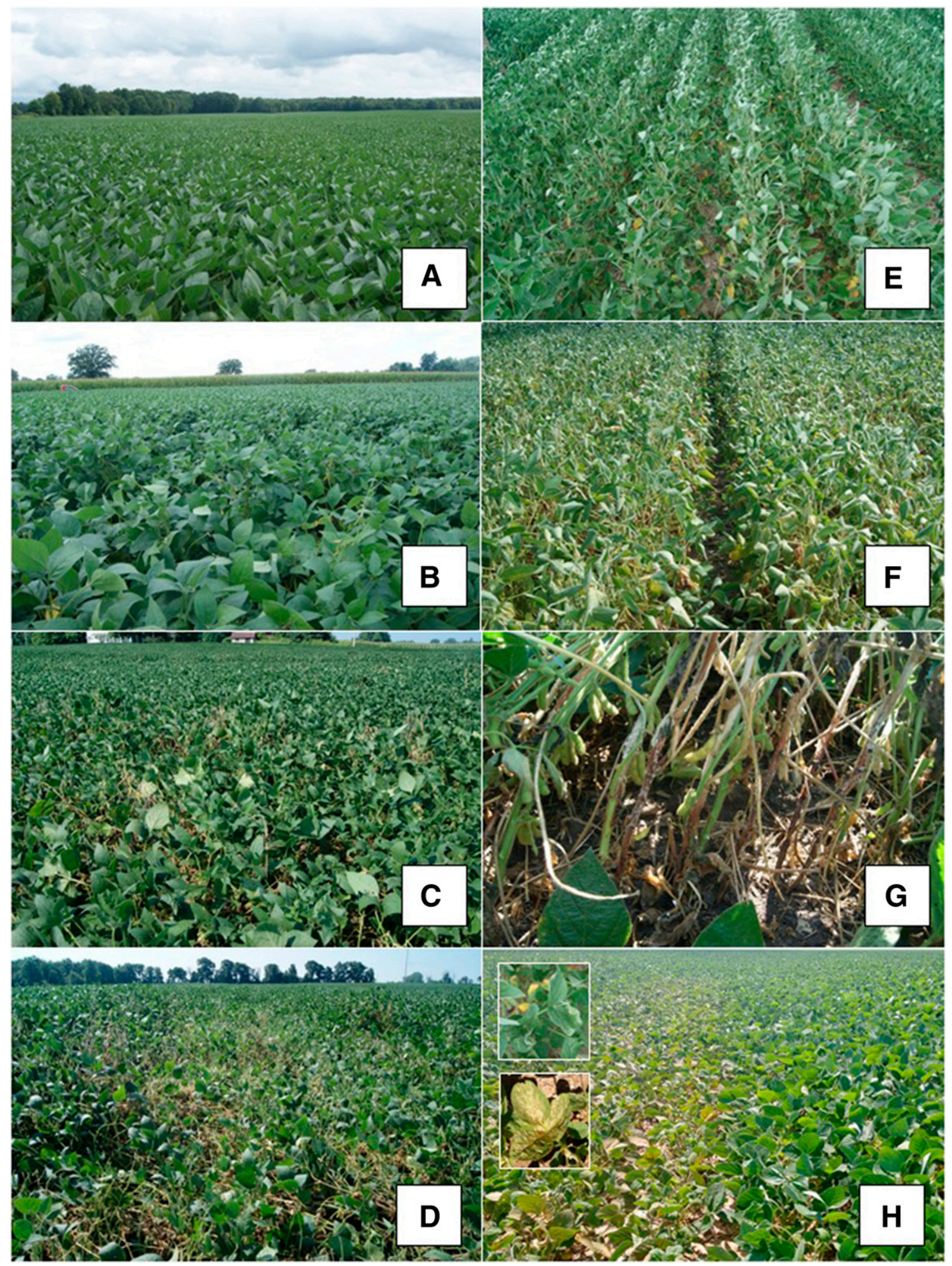

Fig. 3. Soybean fields with A, absence of Sclerotinia stem rot (SSR) or B and C, moderate and $\mathbf{D}$ and $\mathbf{G}$, high levels of SSR. Representation of field $\mathbf{F}$, affected by drought and $\mathbf{E}$, with no closure of soybean canopy. $\mathbf{H}$, Phytotoxicity of lactofen herbicide (left plot) 1 week after application. 
R2 are presented in Supplementary Table S1. The disease levels observed both within and between the 12 environments were highly variable. Among the six environments where SSR developed, the lowest DI ratings were in Trumbull $2015(<7 \%)$ and Wayne 2015 $(<2 \%)$; moderate levels were in Ashtabula 2016 (17.3 to $18.6 \%)$; and the highest levels $(>20 \%)$ were in Trumbull 2014, Licking 2015, and Trumbull 2016. Despite the long history of SSR, no disease was observed in the remaining six environments. Thus, fields with high levels of DI were analyzed separately from those without SSR.

Ascospores of S. sclerotiorum were detected with the blue plate method in one of two fields in 2014, three of five fields in 2015, and none of the five fields in 2016 (Table 1). At the Trumbull location in 2014 and 2015, ascospores were detected 3 and 2 days, respectively, following the R1 fungicide application. In Licking 2015 and Ashtabula 2015, ascospores were detected 7 and 16 days prior to fungicide application at R1. SSR developed in three of four fields where ascospores were detected. Even though ascospores were not detected in 2016, two of five fields had measureable levels of SSR (Fig. 2).

The field in Trumbull 2015 had a very sandy soil and was partially affected by drought in mid-August (Fig. 3F) that negatively influenced disease development. However, the entire field was not affected by drought because SSR was observed in the plots that were near the trees. The plots with symptoms of drought (yellowing and premature senescence) were removed from the data set for analysis.

Canopy closure occurred at approximately R1 in all environments, except Ashtabula 2015 and Wayne 2016. Ashtabula 2015 was planted in late May, and the subsequent rainy and cloudy period in June affected the development of the plants (Fig. 3E), which were shorter and less dense than in the other fields planted with the same cultivars. Plants were very short (approximately 0.5 tall) with a thin canopy at the Wayne 2016 environment because it was planted in June, and high temperatures and dry conditions followed.

The tallest plants (approximately $1.2 \mathrm{~m}$ ) and the densest canopies were observed at the Trumbull 2016 site, which also had one of the highest levels of DI. Plants began to lodge in mid-August and some plots were severely lodged by mid-September (Fig. 3D). Lodging

TABLE 3. Probability values from linear mixed-model covariance analysis of the effects of disease severity index (DSI) in the untreated paired plots as covariate, soybean cultivar (Cult), chemical treatment (Trt), and interaction (Cult-Trt) on arcsine square root-transformed disease incidence (DI), DSI, and yield from field experiments completed in Ohio

\begin{tabular}{|c|c|c|c|c|}
\hline \multirow[b]{2}{*}{ Effect } & \multicolumn{3}{|c|}{ Environment $^{\mathrm{a}}$} & \multirow[b]{2}{*}{$\begin{array}{l}\text { Pooled } \\
\text { data }^{\text {b }}\end{array}$} \\
\hline & $\begin{array}{c}\text { Trumbull } \\
2014\end{array}$ & $\begin{array}{c}\text { Licking } \\
2015\end{array}$ & $\begin{array}{c}\text { Trumbull } \\
2016\end{array}$ & \\
\hline \multicolumn{5}{|l|}{ DI } \\
\hline Covariate & $<0.001$ & 0.039 & $<0.001$ & $<0.001$ \\
\hline Cult & 0.001 & 0.370 & 0.032 & 0.003 \\
\hline Trt & $<0.001$ & $<0.001$ & $<0.001$ & $<0.001$ \\
\hline Cult-Trt & 0.022 & 0.018 & 0.960 & 0.249 \\
\hline \multicolumn{5}{|l|}{ DSI } \\
\hline Covariate & $<0.001$ & 0.019 & $<0.001$ & $<0.001$ \\
\hline Cult & 0.002 & 0.103 & 0.028 & 0.001 \\
\hline Trt & $<0.001$ & $<0.001$ & $<0.001$ & $<0.001$ \\
\hline Cult-Trt & 0.004 & 0.001 & 0.774 & 0.002 \\
\hline \multicolumn{5}{|c|}{ Yield $\left(\mathrm{kg} \mathrm{ha}^{-1}\right)$} \\
\hline Covariate & $<0.001$ & 0.191 & $<0.001$ & $<0.001$ \\
\hline Cult & 0.003 & 0.057 & 0.001 & $<0.001$ \\
\hline Trt & 0.063 & 0.113 & 0.588 & 0.003 \\
\hline Cult-Trt & 0.001 & 0.103 & 0.286 & 0.003 \\
\hline
\end{tabular}

a Block and cultivar nested within block were considered as random factors. Trumbull 2014, Licking 2015, and Trumbull 2016 had mean DI of 26, 35, and $34 \%$, respectively.

b Environment (location-year) block nested within experiment and cultivar nested within block and experiment were considered as random factors for statistical analysis of pooled data. was clearly more severe in the susceptible cultivar. Lodging also occurred in Ashtabula 2016 but was not as severe as in Trumbull 2016.

Covariate, cultivar, and chemical treatment effects on DI, DSI, and yield. Previous studies reported that, when SSR incidence was low, the effects of disease on yield of soybean was inconsistent among environments (Yang et al. 1999). Therefore, DI of $20 \%$ in the untreated check in a specific environment was considered to be the cut-off value to evaluate the effect of the treatments on SSR and yield response. Three environmentsTrumbull 2014, Licking 2015, and Trumbull 2016-had overall mean DI of 26, 35, and 34\%, respectively, and were considered for further statistical analysis to evaluate the effects of cultivar and chemical treatments on disease development and yield. DSI from the untreated paired plots was used as the covariate to account for the variability in disease across a field.

Based on the statistical analysis performed by environment, the covariate was significant $(P<0.05)$ for all variables in all fields, except for yield in Licking $2015(P=0.191)$ (Table 3$)$. There was a significant effect $(P<0.05)$ of soybean cultivar on DI, DSI, and yield for Trumbull 2014 and Trumbull 2016 but not for Licking 2015. Chemical treatment effect was highly significant $(P<0.001)$ on DI and DSI for all three environments. The interaction between cultivar and chemical treatment was significant at two of three environments for DI and DSI and at one of three environments for yield.

In Trumbull 2014, application of boscalid at R1 + R2 or lactofen at $\mathrm{R} 1$ resulted in significantly lower $(P<0.05)$ mean DI and DSI compared with the untreated check for the MS cultivar (Fig. 4). However, for the MR cultivar, only two applications of boscalid at $\mathrm{R} 1+\mathrm{R} 2$ significantly $(P<0.05)$ reduced DI and DSI relative to the untreated check (Fig. 4). Surprisingly, the application of pyraclostrobin at $\mathrm{R} 1$ or $\mathrm{R} 1+\mathrm{R} 2$ resulted in significantly higher $(P<0.05)$ mean DI and DSI compared with the untreated check for the MS cultivar. Similarly, applications of thiophanate-methyl at R1 increased DI and DSI relative to the untreated check for the MS cultivar. The effect of pyraclostrobin and thiophanate methyl on DI for the MR cultivar was numerically higher than but not significantly different from $(P<0.05)$ the untreated check. There was no significant difference $(P<0.05)$ in yield among chemical treatments for the MR cultivar. However, pyraclostrobin at R1 $+\mathrm{R} 2$ significantly reduced yield of the MS cultivar by $379 \mathrm{~kg} \mathrm{ha}^{-1}$ compared with the untreated check (Fig. 5). None of the remaining treatments significantly differed for yield from the untreated check.

In Licking 2015, there was a significant difference $(P<0.05)$ among the chemical treatments for DI and DSI for the MS cultivar but not for the MR cultivar (Fig. 4). Similar to Trumbull 2014, application of pyraclostrobin at R1 significantly increased DI and DSI, whereas applications of boscalid at R1 + R2 or lactofen significantly reduced $(P<0.05)$ DI and DSI compared with the untreated check. However, differences in DI and DSI among treatments did not result in significant differences in yield (Fig. 5).

At the third location with high disease, Trumbull 2016, there was no significant interaction between cultivar and chemical treatment on DI, DSI, and yield (Fig. 4). However, both boscalid applied at R1 + $\mathrm{R} 2$ and lactofen applied at R1 significantly reduced $(P<0.05) \mathrm{DI}$ and DSI compared with the untreated check. Pyraclostrobin applied at R1 significantly increased $(P<0.05)$ DI and DSI compared with the untreated check. There was no significant difference among treatments for yield (Fig. 5).

When the data from the three environments were pooled together (Table 3), the effect of the covariate, cultivar, and chemical treatment for all variables was significant $(P<0.01)$. The interaction between cultivar and chemical treatment was also significant $(P<0.05)$ for DSI and yield but not for DI $(P=0.249)$. Application of boscalid at R1 + R2 and lactofen at R1 had significantly lower $(P<0.05)$ mean DI compared with the untreated check (Fig. 4). Mean DSI was significantly higher $(P<0.05)$ following application of 
pyraclostrobin at R1 for the MR cultivar. For the MS cultivar, significantly higher mean DSI developed with applications of pyraclostrobin at $\mathrm{R} 1(+13.8)$ and $\mathrm{R} 1+\mathrm{R} 2(+10.0)$ or thiophanate at R1 (+8.3) compared with the untreated check, whereas significantly lower DSI with boscalid at R1 (-6.1) and R1 + R2 (-11.4) and lactofen $(-10.9)$ was observed. Yield was not significantly affected $(P>0.05)$ by chemical treatments in the MR cultivar. Yield for the MS cultivar was significantly lower (Fig. 5) with applications of pyraclostrobin at R1 $\left(230 \mathrm{~kg} \mathrm{ha}^{-1}\right)$ or at $\mathrm{R} 1+\mathrm{R} 2\left(256 \mathrm{~kg} \mathrm{ha}^{-1}\right)$, likely due to higher DSI. In contrast, yield was significantly higher
$(P<0.05)$ following applications of boscalid at R1 $+\mathrm{R} 2\left(215 \mathrm{~kg} \mathrm{ha}^{-1}\right)$ than the untreated check.

Relationship between DSI and yield. The effect the interaction between covariate and soybean cultivar on yield was significant (data not shown), therefore, the relationship between DSI and yield was modeled for each cultivar. The final model fitted was $y_{i}=a_{i}+$ $b_{i}$ (DSI), where $a_{i}$ represents the estimated intercept and $b_{i}$ the estimated slope for each cultivar within each environment (Table 4). The intercept for the MR cultivar in Trumbull 2014 was significantly higher compared with the MS cultivars but there was no significant
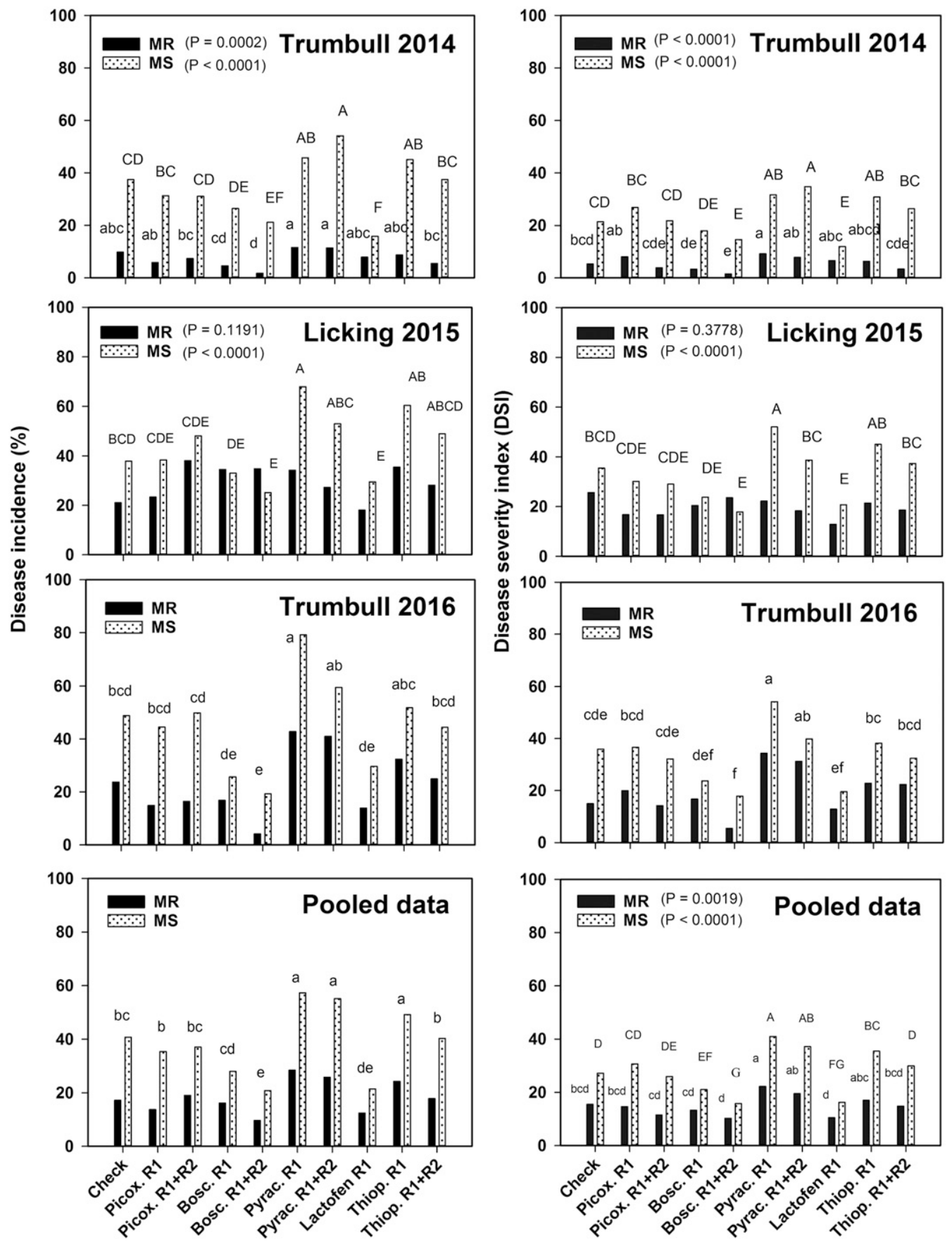

Fig. 4. Least square mean disease incidence (DI, backtransformed arcDI) and disease severity index of Sclerotinia stem rot for soybean cultivars (MR $=$ moderately resistant and MS = moderately susceptible) and chemical treatments from field experiments conducted in Ohio. Chemical treatments were different fungicides $($ Picox. $=$ picoxystrobin, Bosc. $=$ boscalid, Pyrac. $=$ pyraclostrobin, and Thiop. $=$ thiophanate-methyl) and one herbicide $($ Lactofen $)$ applied at R1 (beginning of flowering) or at R1 followed by a second application at R2 (full flowering) (R1 + R2). Means with the same letter do not statistically differ at $P \leq 0.05$. Only the mean comparison for the main effect is shown when the interaction of cultivar and chemical treatment was not significant. When the interaction was significant, mean comparison for the MS cultivar is shown in uppercase letters and for the MR cultivar in lowercase letters. For DI, all statistical analysis and mean comparisons were performed on arcsine square-root-transformed data. 
difference between the intercepts for the susceptible cultivars (Table 5). The slope was not significant $(P>0.05)$ for the MR cultivar in Trumbull 2014 and Licking 2015, indicating that there was no effect on yield with an increase in DSI (Table 4). However, for the MS cultivars, there were negative and significant $(P<0.001)$ slopes as soybean yield decreased with an increase in DSI (Table 4). The slopes were negative and significant $(P<0.001)$ for both cultivars in Trumbull 2016; however, the cultivar with moderate resistance had a loss of soybean at $10.9 \mathrm{~kg} \mathrm{ha}^{-1}$ for each unit of increase in the DSI, whereas the MS cultivar lost $21.5 \mathrm{~kg}$ ha$^{1}$ per unit increase in DSI. When data for the three environments were pooled together, the MR cultivar had significantly a higher intercept than the susceptible cultivar (Table 4). Both cultivars had negative and significant $(P<0.001)$ slopes, where the yield for the MR cultivar decreased by $9.4 \mathrm{~kg} \mathrm{ha}^{-1}$ with each unit increase in DSI, compared with $16.7 \mathrm{~kg} \mathrm{ha}^{-1}$ for the MS cultivar (Table 4).

Cultivar and chemical treatment effects on yield in fields in the absence of SSR. SSR did not develop in 6 of the 12 environments, and in only 1 (Wayne 2016) of these 6 was the effect of chemical treatment on yield statically significant $(P=0.006)$ (Table 6). None of the six environments had a significant interaction between cultivar and treatment on yield $(P>0.05)$. For the pooled data, the effects of cultivar, chemical treatment, and cultivar-chemical treatment interaction were not statistically significant. Yield from the untreated plots was used as the covariate for this analysis. The covariate was highly significant $(P<0.001)$ for all environments and for the pooled data, indicating that soybean yield was highly variable across the fields and that this variability affected yield response

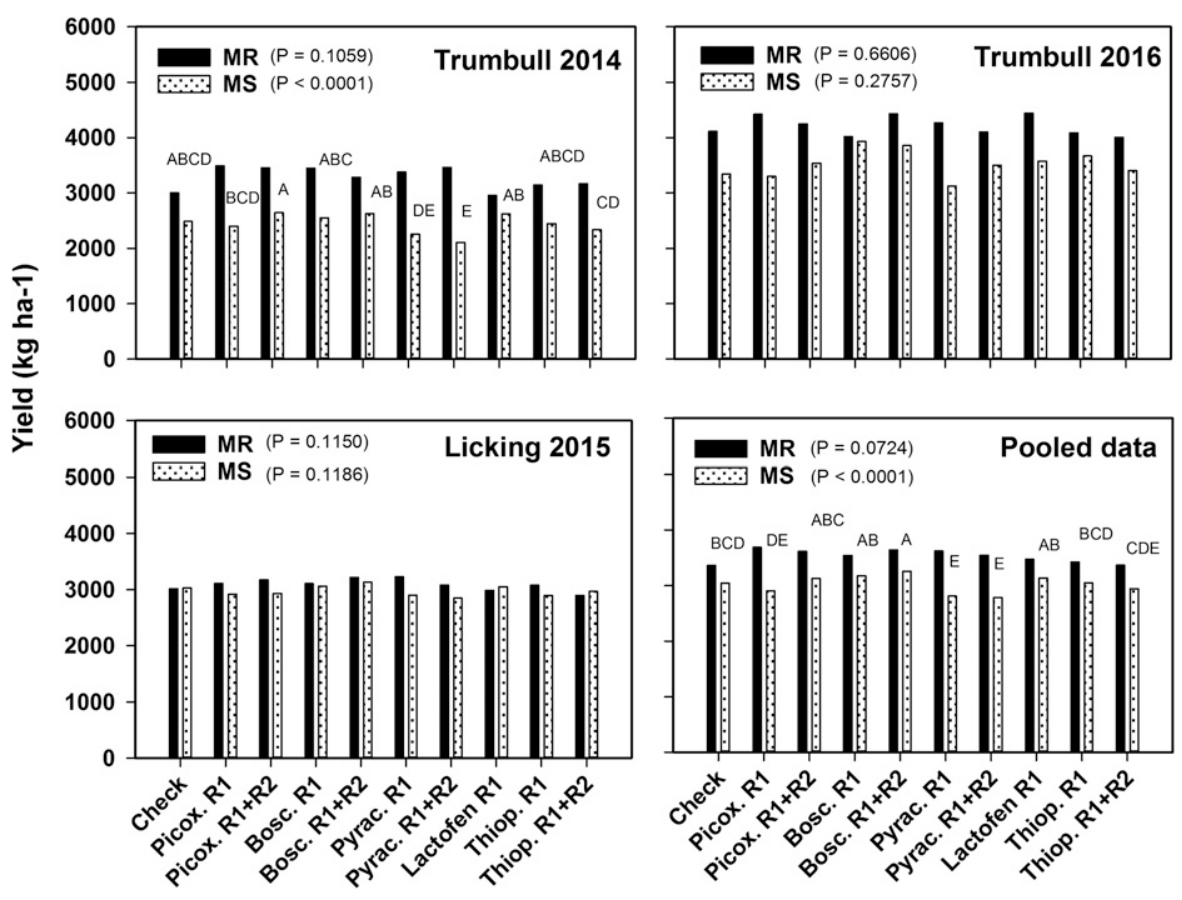

Fig. 5. Least square mean yield of soybean cultivars with different levels of resistance to Sclerotinia stem rot $(\mathrm{MR}=$ moderately resistant and MS $=$ moderately susceptible) and chemical treatments from field experiments conducted in Ohio. Chemical treatments were different fungicides (Picox. $=$ picoxystrobin, Bosc. $=$ boscalid, Pyrac. $=$ pyraclostrobin, Lactofen, and Thiop. $=$ thiophanate-methyl) applied at R1 (beginning of flowering) or at R1 followed by a second application at $\mathrm{R} 2$ (full flowering) (R1 + R2). When interaction was significant, mean comparison for the MS cultivar is shown in uppercase letters and for the MR cultivar in lowercase letters.

TABLE 4. Estimated regression coefficients (Est) and their 95\% confidence intervals (CI), standard errors (SE), and probability values for the relationship between yield (kilograms per hectare) and disease severity index (DSI, predictor) for soybean cultivars with different levels of resistance to Sclerotinia stem rot for each field experiment completed in Ohio where high levels of disease developed

\begin{tabular}{|c|c|c|c|c|c|c|c|}
\hline \multirow[b]{2}{*}{ Environment, cult ${ }^{\mathrm{a}}$} & \multirow[b]{2}{*}{$\mathrm{DSI}^{\mathrm{b}}$} & \multicolumn{3}{|c|}{ Intercept } & \multicolumn{3}{|c|}{ Slope } \\
\hline & & Est $\pm \mathrm{CI}$ & SE & $P$ value & Est $\pm \mathrm{CI}$ & $\mathrm{SE}$ & $P$ value \\
\hline \multicolumn{8}{|l|}{ Trumbull 2014} \\
\hline MS2 & 19.2 & $2,786.6 \pm 215.0$ & 107.8 & $<0.001$ & $-11.0 \pm 6.6$ & 3.4 & 0.001 \\
\hline MS3 & 23.9 & $2,897.8 \pm 256.3$ & 129.2 & $<0.001$ & $-21.4 \pm 7.2$ & 3.7 & $<0.001$ \\
\hline \multicolumn{8}{|l|}{ Licking 2015} \\
\hline \multicolumn{8}{|l|}{ Trumbull 2016} \\
\hline MR & 20.7 & $4,427.4 \pm 181.7$ & 91.0 & $<0.001$ & $-10.9 \pm 6.5$ & 3.3 & 0.001 \\
\hline MS & 31.9 & $4,234.4 \pm 224.5$ & 113.1 & $<0.001$ & $-21.5 \pm 5.6$ & 2.8 & $<0.001$ \\
\hline \multicolumn{8}{|l|}{ Pooled data } \\
\hline MR & 17.0 & $3,668.4 \pm 1452.3$ & 349.7 & 0.008 & $-9.4 \pm 4.0$ & 2.0 & $<0.001$ \\
\hline MS & 25.1 & $3,476.5 \pm 1450.3$ & 350.2 & 0.009 & $-16.7 \pm 2.5$ & 1.3 & $<0.001$ \\
\hline
\end{tabular}

${ }^{a}$ Resistance rating of soybean cultivars (cult) to Sclerotinia stem rot: MR = moderately resistant and MS = moderately susceptible; numbers 1,2 , and 3 represent the code for each of the cultivars.

b Mean DSI from the untreated paired plots used as a covariate. 
to chemical treatment. In Wayne 2016, significantly lower yield was observed with application of lactofen at R1 compared with thiophanate-methyl at R1, thiophanate-methyl at R1 + R2, pyraclostrobin at $\mathrm{R} 1$, and picoxystrobin at $\mathrm{R} 1+\mathrm{R} 2$; however, they did not differ from the untreated check (Fig. 6). One of the most important findings from this study was that, across these six environments, there was no significant cultivar effect (MR versus MS) on soybean yield, suggesting that there was no yield "drag" associated with SSR resistance.

\section{DISCUSSION}

Management guidelines for SSR of soybean in Ohio are more than 10 years old and were developed based on older fungicide products and soybean cultivars that were highly susceptible. The recent outbreaks of SSR in the state, along with the release of newer fungicides and cultivars with higher levels of resistance, led to a renewed interest in evaluating disease management practices. The efficacy of chemical control when soybean cultivars with MR and MS levels of resistance were grown was evaluated in a total of 12 environments. In this study, the incidence of SSR in 6 of the 12 environments was low $(<5 \%)$ to moderate ( 26 to $35 \%$ ) compared with other states such as Michigan and Wisconsin where higher DI have been reported (Byrne and Chilvers 2014, 2015, 2016; Kirk and Schafer 2013; Smith et al. 2014, 2015).

Crop development, pathogen reproduction, disease initiation, and environmental factors are all interrelated in the SSR-soybean pathosystem (Boland and Hall 1988a). This helps to explain why this disease did not occur when primary inoculum was detected during the flowering period, as noted for Ashtabula 2015. Canopy closure did not occur in this environment and it may have affected the microclimate. It is important to highlight that flowering had initiated at approximately the same time as canopy closure in almost all of the environments. When the soybean canopy is denser, there is less air circulation and lower solar radiation; consequently, it tends to be cooler and have higher humidity (Blad et al. 1978; Boland and Hall 1987, 1988a; Weiss et al. 1980a). These factors may influence sclerotia germination (Boland and Hall 1988a), apothecia development (Boland and Hall 1988a; Schwartz and Steadman 1978), and ascospore survival (Caesar and Pearson 1983) and result in higher levels of disease (Blad et al. 1978; Boland and Hall 1988a; Weiss et al. 1980a).

The resistance reactions of the soybean cultivars used in this field study to infections of $S$. sclerotiorum were consistent with the ratings provided by the seed companies. The cultivars flowered at approximately the same time and with similar canopy density in each environment. The cultivars with higher levels of resistance had very low overall DI and disease severity. These results reinforce the idea that the currently available cultivars with moderate resistance ratings for SSR should be considered by soybean producers in fields with a history of this disease. The fallacy that resistant cultivars, by allocating more resources to defense, would have a negative impact on yield (Bergelson and Purrington 1996) is not supported by our findings.

The chemical treatments had a greater impact on reducing DI and DSI and protecting yield when MS cultivars were planted. Among all the fungicides evaluated in this study, two application of boscalid, which is an SDHI, resulted in the greatest reduction in DI and DSI when compared with the untreated check. However, higher yields compared with the untreated check were not consistently observed when the fungicide was applied. A similar scenario was reported previously for canola, where the reduction in disease severity not always reflected in higher yield (Bradley et al. 2006).

Thiophanate-methyl is a fungicide from the methyl benzimidazole carbamate group that acts on the $\beta$-tubulin assembly in mitosis (FRAC 2017). In this study, there was no reduction in DI or DSI with application of thiophanate-methyl, which is consistent with observations reported by Sumida et al. (2015) but contrary to other, previous studies in which thiophanate-methyl was reported to be an effective option in controlling SSR of soybean (Mueller et al. 2002, 2004).

TABLE 5. Estimated difference (Est) between intercepts and slopes, and their half 95\% confidence intervals (CI), standard errors (SE), and probability values for the relationship between yield (kilograms per hectare) and disease severity index (DSI, predictor) for soybean cultivars with different levels of resistance to Sclerotinia stem rot for each experiment conducted in Ohio

\begin{tabular}{|c|c|c|c|c|c|c|c|}
\hline \multirow[b]{2}{*}{ Environment } & \multirow[b]{2}{*}{ Comparison $^{\mathrm{a}}$} & \multicolumn{3}{|c|}{ Intercept } & \multicolumn{3}{|c|}{ Slope } \\
\hline & & Est $\pm \mathrm{CI}$ & SE & $P$ & Est $\pm \mathrm{CI}$ & SE & $P$ \\
\hline \multirow[t]{5}{*}{ Trumbull 2014} & MR vs. MS1 & $397.9 \pm 281.8$ & 140.3 & 0.007 & $11.7 \pm 21.9$ & 11.2 & 0.294 \\
\hline & MR vs. MS2 & $532.7 \pm 284.7$ & 141.9 & 0.000 & $3.8 \pm 22.3$ & 11.3 & 0.741 \\
\hline & MS1 vs. MS2 & $134.8 \pm 289.1$ & 144.4 & 0.354 & $-7.9 \pm 8.6$ & 4.4 & 0.068 \\
\hline & MS1 vs. MS3 & $23.7 \pm 320.7$ & 161.0 & 0.883 & $2.3 \pm 9.0$ & 4.6 & 0.61 \\
\hline & MS2 vs. MS3 & $-111.1 \pm 322.9$ & 162.1 & 0.495 & $10.3 \pm 9.8$ & 4.9 & 0.038 \\
\hline Pooled data & MR vs. MS & $194.9 \pm 172.2$ & 86.6 & 0.027 & $7.4 \pm 4.7$ & 2.4 & 0.002 \\
\hline
\end{tabular}

${ }^{a}$ Resistance rating of soybean cultivars to Sclerotinia stem rot: MR = moderately resistant and MS = moderately susceptible; numbers 1,2 , and 3 represent the code for each of the cultivars.

TABLE 6. Probability values from linear mixed-model covariance analysis for covariate (COV) (yield from untreated paired plots), soybean cultivar (Cult), chemical treatment (Trt), and the interaction effect on soybean yield (kilograms per hectare) for the field experiments where Sclerotinia stem rot was not present

\begin{tabular}{lcccrrrr}
\hline & \multicolumn{9}{c}{ Environment $^{\mathrm{a}}$} \\
\cline { 2 - 7 } Effect & Wayne 2014 $^{\mathrm{b}}$ & Ashtabula 2015 & Tuscarawas 2015 & Knox 2016 & Tuscarawas 2016 $^{\text {Wayne 2016 }}$ & Pooled $^{\mathrm{c}}$ \\
\hline COV & $\ldots$ & $<0.0001$ & $<0.0001$ & $<0.0001$ & $<0.0001$ & $<0.0001$ \\
Cult & 0.2932 & 0.0555 & 0.8253 & 0.8690 & 0.2910 & 0.1725 \\
Trt & 0.3626 & 0.6432 & 0.5342 & 0.3623 & 0.2309 & 0.0828 \\
Cult-Trt & 0.2696 & 0.8107 & 0.5446 & 0.9008 & 0.3367 & 0.0063 \\
\hline
\end{tabular}

a Block and cultivar nested within block were considered as random factors.

b Untreated paired plots were not added to the experimental design; therefore, no covariate was considered in the statistical analysis. This site was not added to the analysis with the pooled data.

${ }^{c}$ Pooled data. Environment (location-year) block nested within experiment, and cultivar nested within block and experiment were considered as random factors for statistical analysis of pooled data. 
Possible explanations for low fungicide efficacy include but are not limited to poor coverage, fungicide rate, proper mixing, sprayer calibration, and environmental conditions. The coverage can be influenced by canopy density, droplet size, and spray volume (Derksen et al. 2008). It was shown that, under high disease pressure, no consistent control of SSR was observed with application of benomyl and thiophanate-methyl but that, under low disease pressure, the fungicides were able to reduce disease when the spray system allowed for penetration of the soybean canopy to the lower nodes (Mueller et al. 2002). However, because other treatments in this study with greater efficacy were applied using the same spray parameters as thiophanate-methyl, poor coverage is not a likely explanation for the reduced fungicide efficacy. Another possible explanation for reduced efficacy would be fungal resistance to thiophanate-methyl. However, it is currently thought that there is a low risk for development of resistance in S. sclerotiorum (FRAC 2013) to this fungicide. One isolate of $S$. sclerotiorum was identified as resistant to thiophanatemethyl in Brazil (Lehner et al. 2015), with rate of mycelial growth, sclerotia production, and aggressiveness similar to that of sensitive isolates, indicating that it could outcompete with other isolates in the field treated with the fungicide. The potential risk for resistance and lack of efficacy in these trials indicates that further investigations are needed to verify whether resistant isolates of S. sclerotiorum are present in soybean fields in Ohio.

The increase in DI and DSI following applications of pyraclostrobin fungicide compared with the untreated control has not been previously reported. It is interesting to note that picoxystrobin, the other QoI fungicide used in this study, did not result in similar increases in disease compared with pyraclostrobin. Although these fungicides are from the same fungicide group, they belong to different chemical groups, and this could, in part, explain differences in disease response. Pyraclostrobin is classified in the methoxycarbamates chemical group, whereas picoxystrobin is part of the methoxy-acrylate chemical group (FRAC 2017). Beyond their direct effects on fungal pathogens, QoI fungicides have been reported to have some effects on plant physiology (Bertelsen et al. 2001; DiazEspejo et al. 2012; Grossmann and Retzlaff 1997; Grossmann et al. 1999). Enhancement of plant resistance in tobacco to Tobacco mosaic virus and Pseudomonas syringae following applications of pyraclostrobin have been reported (Herms et al. 2002). They proposed that
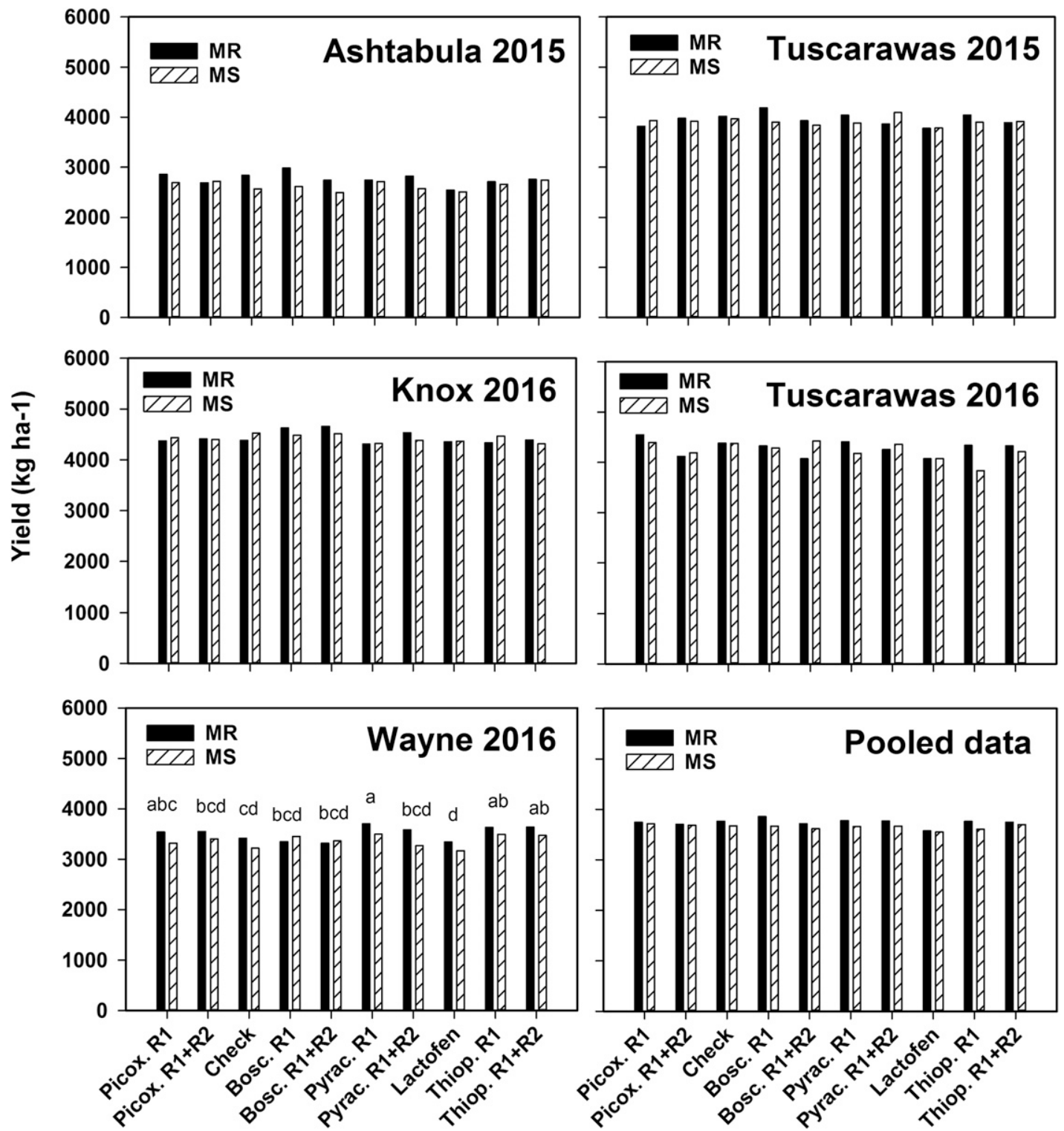

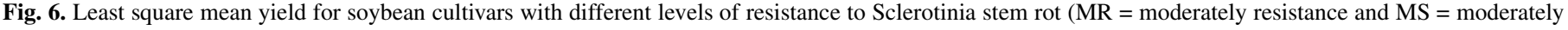

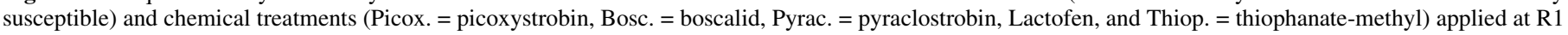

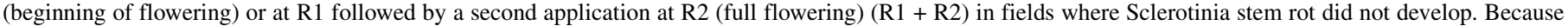

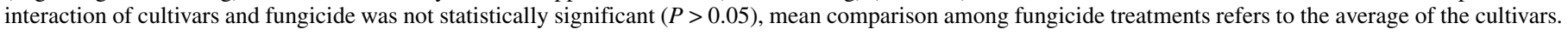


pyraclostrobin may act downstream of salicylic acid (SA) in the signal transduction network or by functioning independently of SA. Thus, the increase of SSR in soybean following these applications may be a consequence of the interaction of S. sclerotiorum and the changes in plant physiology due to pyraclostrobin. However, additional research is required to test this hypothesis.

The majority of the fungicides currently available for management of SSR should be applied in a preventative manner as protectants because they are more effective in early stages of infection and disease development. Previous studies indicated that fungicides applied at the beginning of flowering (R1) prior to the arrival of inoculum reduced SSR of soybean (Mueller et al. 2004). In addition, considering that some of these fungicides have very limited mobility in the plant and that the majority of soybean cultivars grown in Ohio have indeterminate growth habit, a second fungicide application at full flowering (R2) could provide a wider window of protection. However, among the fungicides that did reduce DI, two applications of boscalid did not significantly reduce disease compared with a single application at R1. Thus, the cost associated with a second application may not be economical feasible, emphasizing that the decision-making process regarding a chemical application should take into account not only the fungicide efficacy but also the cost associated with its use and the return on the investment.

It is unlikely that lactofen affects $S$. sclerotiorum directly (Dann et al. 1999). This herbicide causes phytotoxicity on soybean plants as a result of the inhibition of the protoporphyrinogen oxidase, a key enzyme in the chlorophyll/heme biosynthetic pathway (Sanyal and Shrestha 2008). A week after the application, soybean plants treated with lactofen were shorter and the leaves were distorted in shape and brown to red-brown in color (Fig. 2H). The plants eventually recovered, and only a few visible symptoms were observed 3 weeks after application. A dense soybean canopy is often associated with SSR due to high humidity and cooler temperature conditions (Blad et al. 1978; Boland and Hall 1987, 1988a; Weiss et al. 1980a). Hence, delaying canopy closure during flowering by lactofen application likely limited environmental conditions conducive for infection and disease development, and may explain the lower DI and DSI. This was consistent with previous observations, where disease severity was suppressed by 40 to $60 \%$ when lactofen was applied under high disease pressure (Dann et al. 1999). Another possible explanation for suppression in disease severity is that lactofen may increase phytoalexin production (Dann et al. 1999; Landini et al. 2003; Levene et al. 1998) as well as induce the expression of defense-related genes (Graham 2005); however, the levels of phytoalexins in the stem compared with leaves may not totally explain the protection against SSR (Nelson et al. 2002). Although lactofen has been reported to reduce disease severity, the negative impact on yield by approximately 10 to $15 \%$ when SSR did not develop (Dann et al. 1999; Nelson et al. 2007) has been considered to be one the main constraints to its use. Based on the results from this study, there were no significant differences in yield following lactofen applications compared with the untreated check under moderate levels of SSR. When disease was absent, none of the six fields had significantly lower yields when lactofen was applied compared with the untreated check. Previous reports of the effect of lactofen on yield were observed when commercial products such as Cobra (Valent U.S.A. Corporation, Walnut Creek, CA) were applied. In this study, the commercial product Phoenix (Valent U.S.A. Corporation), which is a different formulation with an added adjuvant/surfactant system, was used. Therefore, the hypothesis that newer formulations of herbicides containing lactofen may have no or less negative impact on yield compared with older formulation still warrants further investigation because these were not side-by-side comparisons. However, under the low to moderate disease conditions of this study, both with and without the development of SSR, lactofen had no effect on yield, which raises questions about the value of both fungicides and lactofen for the management of SSR.
SSR of soybean tends to occur in an aggregated spatial pattern within fields (Boland and Hall 1988b; Hartman et al. 1998). The assessment of disease and yield in the untreated paired plots allowed us to account for some of the spatial variability by using DSI from the untreated plots as a covariate in the statistical analyses. Because features of analysis of variance and regression are combined in the analysis of covariance (Snedecor and Cochran 1980) with adjustment of the treatment means to the same covariate value, it accounted for experimental error in the field trials, reducing the residual mean square and increasing precision (Clewer and Scarisbrick 2001). Lower $P$ values were obtained when the covariate was added to the analysis, changing the interpretation of significance, especially for marginal $P$ values to 0.05 . Use of untreated paired plots was more effective in fields where blocking was not enough to account for variability across the field, particularly for those environments where plant development was compromised by heavy rains or drought. The disadvantage of using paired plots, however, was the increase in the overall experimental area which effectively doubled the size of the study and resources required to collect all of the data.

The blue plate method identified the presence of inoculum in four fields in 2014 and 2015, three of which had SSR later in the season, but inoculum was not detected using this method in 2016, when the disease developed in two of five fields. The blue plate method has the potential to be a decision aid for fungicide application in soybean, similarly to what has been used in common bean (Harveson et al. 2010), but the sampling protocols would need to be improved regarding the number of plates used, location of the plates in a field, how often sampling would be performed, and so on. Other methods of inoculum detection have been tested, such as the Burkard sampler with quantitative polymerase chain reaction (Parker et al. 2014; Rogers et al. 2009), which can accelerate the detection process compared with traditional method with blue plates that may take up to 3 days. Nevertheless, there is still a need to develop detection tools that are more accessible for growers. Disease forecast models have been developed and validated for diseases caused by S. sclerotiorum in canola (Bom and Boland 2000), carrot (Foster et al. 2011), and lettuce (Clarkson et al. 2007). A disease forecast model for SSR of soybean is under development and validation in Wisconsin (Smith and Willbur 2016), which may help in improving the prediction of SSR as a fungicide decision support system.

Based on results of this study, use of cultivars with moderate levels of resistance is effective to reduce incidence and severity of soybean in Ohio. If susceptible cultivars are grown in fields with a history of the disease, a fungicide application may be required when environmental conditions are highly conducive for disease development. Boscalid fungicide and lactofen herbicide were the treatments with the highest efficacy in reducing disease; however, this did not always resulted in yield increases. It is unlikely that two fungicide applications would protect plants significantly enough to warrant the extra cost associated with the treatment under Ohio growing conditions. The cool and moist environmental conditions that favor apothecia development and infection during flowering may occur in Ohio for a shorter period of time than in regions further to the north. Therefore, the results reported here may not be completely translated for regions where higher levels of the disease are consistently observed. The research presented here can help guide application decisions by producers, extension educators, and consultants regarding the management of SSR of soybean in Ohio and regions with low to moderate disease pressure.

\section{ACKNOWLEDGMENTS}

We thank all soybean growers, crop consultants, and extension educators who assisted us with this research; members of the Soybean Pathology Laboratory for assistance with data collection; Tech Services, Inc. for assistance with the harvest; and DuPont Pioneer and Monsanto for contributing soybean seed and resistance ratings for these studies. Salaries and research support for this project were provided by State and Federal 
Funds appropriated to the Ohio Agricultural Research and Development Center, The Ohio State University, and the National Institute of Food and Agriculture, United States Department of Agriculture (USDA), Hatch project for Development of Disease Management Strategies for Soybean Pathogens in Ohio OHO01303. Graduate student J. Huzar-Novakowiski was funded by Coordenação de Aperfeiçoamento de Pessoal de Nível Superior (CAPES) through the Science without Borders Program from Brazil. This project was also funded, in part, through check-off dollars provided by the Ohio Soybean Council and through the USDA National Institute of Food and Agriculture 20147000622507.

\section{LITERATURE CITED}

Abawi, G. S., and Grogan, R. G. 1975. Source of primary inoculum and effects of temperature and moisture on infection of beans by Whetzelinia sclerotiorum. Phytopathology 65:300-309.

Adams, P. B., and Ayers, W. A. 1979. Ecology of Sclerotinia species. Phytopathology 69:896-898.

Bergelson, J., and Purrigton, C. B. 1996. Surveying patterns in the cost of resistance in plants. Am. Nat. 148:536-558.

Bertelsen, J. R., Neergaard, E., and Smedegaard-Petersen, V. 2001. Fungicidal effects of azoxystrobin and epoxiconazole on phyllosphere fungi, senescence and yield of winter wheat. Plant Pathol. 50:190-205.

Blad, B. L., Steadman, J. R., and Weiss, A. 1978. Canopy structure and irrigation influence white mold disease and microclimate of dry edible beans. Phytopathology 68:1431-1437.

Boland, G. J., and Hall, R. 1987. Epidemiology of white mold of white bean in Ontario. Can. J. Plant Pathol. 9:218-224.

Boland, G. J., and Hall, R. 1988a. Epidemiology of Sclerotinia stem rot of soybean in Ontario. Phytopathology 78:1241-1245.

Boland, G. J., and Hall, R. 1988b. Relationships between the spatial pattern and number of apothecia of Sclerotinia sclerotiorum and stem rot of soybean. Plant Pathol. 37:329-336.

Boland, G. J., and Hall, R. 1994. Index of plant host of Sclerotinia sclerotiorum. Can. J. Plant Pathol. 16:93-108.

Bom, M., and Boland, G. J. 2000. Evaluation of disease forecasting variables for Sclerotinia stem rot (Sclerotinia sclerotiorum) of canola. Can. J. Plant Sci. 80:889-898.

Bradley, C. A., Lamey, H. A., Endres, G. J., Henson, R. A., Hanson, B. K., McKay, K. R., Halvorson, M., LeGare, D. G., and Porter, P. M. 2006. Efficacy of fungicides for control of Sclerotinia stem rot of canola. Plant Dis. 90:1129-1134.

Buzzel, R. I., Welacky, T. W., and Anderson, T. R. 1993. Soybean cultivar reaction and row width effect on Sclerotinia stem rot. Can. J. Plant Pathol. 73:1169-1175.

Byrne, A. M., and Chilvers, M. I. 2014. Efficacy of foliar fungicides for white mold control in soybean in Michigan, 2013. Online publication. Plant Dis. Manage. Rep. 8:FC174.

Byrne, A. M., and Chilvers, M. I. 2015. Efficacy of foliar fungicides for white mold management of soybean in Michigan, 2014. Online publication. Plant Dis. Manage. Rep. 9:FC055.

Byrne, A. M., and Chilvers, M. I. 2016. Efficacy of foliar fungicides for white mold management of soybean in Michigan, 2015. Online publication. Plant Dis. Manage. Rep. 10:FC023.

Caesar, A. J., and Pearson, R. C. 1983. Environmental factors affecting survival of ascospores of Sclerotinia sclerotiorum. Phytopathology 73: 1024-1030.

Cheng, J., Yuan, C., and Graham, T. L. 2011. Potential defense-related prenylated isoflavones in lactofen-induced soybean. Phytochemistry 72: 875-881.

Clarkson, J. P., Phelps, K., Whipps, J. M., Young, C. S., Smith, J. A., and Watling, M. 2007. Forecasting disease of lettuce: A predictive model for carpogenic germination of Sclerotinia sclerotiorum sclerotia. Phytopathology 97:621-631.

Clewer, A. G., and Scarisbrick, D. H. 2001. Pages 256-271 in: Practical Statistics and Experimental Design for Plant and Crop Science. Wiley, Chichester, UK.

Dann, E. K., Diers, B. W., and Hammerschmidt, R. 1999. Suppression of Sclerotinia stem rot of soybean by lactofen herbicide treatment. Phytopathology 89:598-602.

Derksen, R. C., Zhu, H., Ozkan, H. E., Hammond, R. B., Dorrance, A. E., and Spongberg, A. L. 2008. Determining the influence of spray quality, nozzle type, spray volume and air-assisted application strategies on deposition of pesticides in soybean canopy. Trans. ASABE 51:1529-1537.

Diaz-Espejo, A., Cuevas, M. V., Ribas-Carbo, M., Flexas, J., Martorell, S., and Fernandez, J. E. 2012. The effect of strobilurins on leaf gas exchange, water use efficiency and ABA content in grapevine under field conditions. J. Plant Physiol. 169:379-386.
Foster, A. J., Kora, C., McDonald, M. R., and Boland, G. J. 2011. Development and validation of a disease forecast model for Sclerotinia rot of carrot. Can. J. Plant Pathol. 22:771-780.

FRAC. 2013. Pathogen risk list. Online publication. Fungicide Resistance Action Committee. http://www.frac.info/docs/default-source/publications/ pathogen-risk/pathogen-risk-list.pdf?sfvrsn $=8$

FRAC. 2017. FRAC Code List 2017: Fungicides sorted by mode of action (including FRAC Code numbering). Online publication. Fungicide Resistance Action Committee. http://www.frac.info/docs/default-source/ publications/frac-code-list/frac-code-list-2017-final.pdf?sfvrsn=2

Graham, M. Y. 2005. The diphenylether herbicide lactofen induces cell death and expression of defense-related genes in soybean. Plant Physiol. 139: 1784-1794.

Grau, C. R., Radke, V. L., and Gillespie, F. L. 1982. Resistance of soybean cultivars to Sclerotinia sclerotiorum. Plant Dis. 66:506-508.

Grogan, R. G., and Abawi, G. S. 1975. Influence of water potential on growth of Whetzelinia sclerotiorum. Phytopathology 65:122-138.

Grossmann, K., Kwiatkowski, J., and Caspar, G. 1999. Regulation of phytohormone levels, leaf senescence and transpiration by the strobilurin kresoxim-methyl in wheat (Triticum aestivum). J. Plant Physiol. 154: 805-808.

Grossmann, K., and Retzlaff, G. 1997. Bioregulatory effects of the fungicidal strobilurin kresoxim-methyl in wheat (Triticum aestivum). Pestic. Sci. 50: 11-20.

Guo, X., Wang, D., Gordon, S. G., Helliwell, E., Smith, T., Berry, S. A., St. Martin, S. K., and Dorrance, A. E. 2008. Genetic mapping of QTLs underlying partial resistance to Sclerotinia sclerotiorum in soybean PI 391589A and PI 391589B. Crop Sci. 48:1129-1139.

Hartman, G. L., Kull, L., and Huang, Y. H. 1998. Occurrence of Sclerotinia sclerotiorum in soybean fields in East-Central Illinois and enumeration of inocula in soybean seed lots. Plant Dis. 82:560-564.

Harveson, R. M., Steadman, J. R., and Urrea, C. A. 2010. Integrating planting dates and fungicide applications for managing white mold of dry beans in Western Nebraska. Online publication. Plant Health Prog. doi:10.1094/ PHP-2010-0701-02-RS

Herms, S., Seehaus, K., Koehle, H., and Conrath, U. 2002. A strobilurin fungicide enhances the resistance of tobacco against Tobacco mosaic virus and Pseudomonas syringae pv. tabaci. Plant Physiol. 130:120-127.

Hoffman, D. D., Diers, B. W., Hartman, G. L., Nickell, C. D., Nelson, R. L., Pedersen, W. L., Cober, E. R., Graef, G. L., Steadman, J. R., Grau, C. R., Nelson, B. D., del Rio, L. E., Anderson, T., Poysa, V., Rajcan, I., and Stienstra, W. C. 2002. Selected soybean plant introductions with partial resistance to Sclerotinia sclerotiorum. Plant Dis. 86:971-980.

Huynh, T. T., Bastien, M., Iquira, E., Turcotte, P., and Belzile, F. 2010. Identification of QTLs associated with partial resistance to white mold in soybean using field-based inoculation. Crop Sci. 50:969-979.

Huzar Novakowiski, J. H., Winger, J., Martin, C., and Dorrance, A. E. 2016. Effect of fungicide application for management of Sclerotinia stem rot in Ashtabula County, OH, 2015. Online publication. Plant Dis. Manage. Rep. 10:FC049.

Kim, H. S., and Diers, B. W. 2000. Inheritance of partial resistance to Sclerotinia stem rot in soybean. Crop Sci. 40:55-61.

Kim, H. S., Hartman, G. L., Manandhar, J. B., Graef, G. L., Steadman, J. R., and Diers, B. W. 2000. Reaction of soybean cultivars to Sclerotinia stem rot in field, greenhouse, and laboratory evaluations. Crop Sci. 40:665-669.

Kirk, W. W., and Schafer, R. 2013. Evaluation of fungicides for control of white mold in soybean, Montcalm, MI, 2011. Plant Dis. Manage. Rep. 6: FC025 Online publication.

Kull, L. S., Vuong, T. D., Powers, K. S., Eskridge, K. M., Steadman, J. R., and Hartman, G. L. 2003. Evaluation of resistance screening methods for Sclerotinia stem rot of soybean and dry bean. Plant Dis. 87:1471-1476.

Landini, S., Graham, M. Y., and Graham, T. L. 2003. Lactofen induces isoflavone accumulation and glyceollin elicitation competency in soybean. Phytochemistry 62:865-874.

Lehner, M. S., Paula Júnior, T. J., Silva, R. A., Vieira, R. F., Carneiro, J. E. S., Schnabel, G., and Mizzubuti, E. S. G. 2015. Fungicide sensitivity of Sclerotinia sclerotiorum: A thorough assessment using discriminatory dose, $\mathrm{EC}_{50}$, high-resolution melting analysis, and description of new point mutation associated with thiophanate-methyl resistance. Plant Dis. 99: 1537-1543.

Levene, B. C., Owen, M. D. K., and Tylka, G. L. 1998. Response of Soybean cyst nematodes and soybeans (Glycine max) to herbicides. Weed Sci. 46: 264-270.

Martin, C., and Dorrance, A. 2014. Effect of foliar applied fungicides on Sclerotinia stem rot in soybean in Trumbull County, OH, 2013. Online publication. Plant Dis. Manage. Rep. 9:FC043.

Martin, C., and Dorrance, A. 2015. Effect of fungicides on Sclerotinia stem rot in soybean in Trumbull County, OH, 2014. Online publication. Plant Dis. Manage. Rep. 9:FC053. 
Miklas, P. N., Porter, L. D., Kelly, J. D., and Myers, J. R. 2013. Characterization of white mold disease avoidance in common bean. Eur. J. Plant Pathol. 135:525-543.

Mueller, B., Smith, D. L., Willbur, J., and Chapman, S. 2016. Evaluation of foliar fungicides for control of Sclerotinia stem rot of soybean in Arlington Wisconsin, 2015. Plant Dis. Manage. Rep. 10:FC050 Online publication.

Mueller, D. S., Bradley, C. A., Grau, C. R., Gaska, J. M., Kurle, J. E., and Pedersen, W. L. 2004. Application of thiophanate-methyl at different host growth stages for management of Sclerotinia stem rot in soybean. Crop Prot. 23:983-988.

Mueller, D. S., Dorrance, A. E., Derksen, R. C., Ozkan, E., Kurle, J. E., Gaska, J. M., Hartman, G. L., Bradley, C. A., and Pedersen, W. L. 2002. Efficacy of fungicides on Sclerotinia sclerotiorum and their potential for control of Sclerotinia stem rot on soybean. Plant Dis. 86:26-31.

Nelson, K. A., Renner, K. A., and Hammerschmidt, R. 2002. Cultivar and herbicide selection affects soybean development and the incidence of Sclerotinia stem rot. Agron. J. 94:1270-1281.

Nelson, K. A., Rottinghaus, G. E., and Nelson, T. E. 2007. Effect of lactofen application timing on yield and isoflavone concentration in soybean seed. Agron. J. 99:645-649.

Parker, M. L., McDonald, M. R., and Boland, G. J. 2014. Evaluation of air sampling and detection methods to quantify airborne ascospores of Sclerotinia sclerotiorum. Plant Dis. 98:32-42.

Rogers, S. L., Atkins, S. D., and West, J. S. 2009. Detection and quantification of airborne inoculum of Sclerotinia sclerotiorum using quantitative PCR. Plant Pathol. 58:324-331.

Rousseau, G., Thanh, T. H., Dostaler, D., and Rioux, S. 2004. Greenhouse and field assessments of resistance in soybean inoculated with sclerotia, mycelium, and ascospores of Sclerotinia sclerotiorum. Can. J. Plant Pathol. 84:615-623.

Sanyal, D., and Shrestha, A. 2008. Direct effect of herbicides on plant pathogens and disease development in various cropping systems. Weed Sci. 56:155-160.

Schwartz, H. F., and Steadman, J. R. 1978. Factors affecting sclerotium populations of, and apothecium production by Sclerotinia sclerotiorum. Phytopathology 68:383-388.
Smith, D. L., Chapman, S., and Conley, S. P. 2015. Evaluation of "curative" fungicide treatments for control of Sclerotinia stem rot of soybean in Wisconsin, 2014. Plant Dis. Manage. Rep. 9:FC028 Online publication.

Smith, D. L., Jensen, B., and Conley, S. P. 2014. Evaluation of fungicides for control of Sclerotinia stem rot of soybean in Wisconsin, 2013. Online publication. Plant Dis. Manage. Rep. 8:FC184.

Smith, D. L., and Willbur, J. 2016. Wisconsin White Mold Risk Map. Online publication. Wisconsin Crop Manager. http://ipcm.wisc.edu/blog/2016/07/ $8248 /$

Snedecor, G. W., and Cochran, W. G. 1980. Pages 365-370 in: Statistical Methods, 7th ed. Iowa State University Press, Ames.

Steadman, J. R., Marcinkowska, J., and Rutledge, S. 1994. A semi-selective medium for isolation of Sclerotinia sclerotiorum. Can. J. Plant Pathol. 16:68-70.

Sumida, C. H., Canteri, M. G., Peitl, D. C., Tibolla, F., and Orsini, I. P. 2015. Chemical and biological control of Sclerotinia stem rot in the soybean crop. Cienc. Rural 45:760-766.

Vuong, T. D., Hoffman, D. D., Diers, B. W., Miller, J. F., Steadman, J. R., and Hartman, G. L. 2004. Evaluation of soybean, dry bean, and sunflower fore resistance to Sclerotinia sclerotiorum. Crop Sci. 44:777-783.

Weiss, A., Hipps, L. E., Blad, B. L., and Steadman, J. R. 1980a. Comparison of within-canopy microclimate and white mold disease (Sclerotinia sclerotiorum) development in dry edible beans as influenced by canopy structure and irrigation. Agric. Meteorol. 22:11-21.

Weiss, A., Kerr, E. D., and Steadman, J. R. 1980b. Temperature and moisture influences on development of white mold disease (Sclerotinia sclerotiorum) on Great Northern beans. Plant Dis. 64:757-759.

Willbur, J. F., Ding, S., Marks, M. E., Lucas, H., Grau, C. R., Groves, C. L., Kabbage, M., and Smith, D. L. 2017. Comprehensive Sclerotinia stem rot screening of soybean germplasm requires multiple isolates of Sclerotinia sclerotiorum. Plant Dis. 101:344-353.

Yang, X. B., Lundeen, P., and Uphoff, M. D. 1999. Soybean varietal response and yield loss caused by Sclerotinia sclerotiorum. Plant Dis. 83: 456-461. 